\title{
Public Health Emergencies: a new peacekeeping mission? Insights from UNMIL's role in the Liberia Ebola outbreak
}

\begin{abstract}
The meeting of the UN Security Council on 18 September 2014 represented a major turning-point in the international response to the Ebola outbreak then underway in West Africa. However, in the light of widespread criticisms over the tardiness of the international response, there is a case to be made that the UN, and particularly the Security Council, failed to make best use of a potential resource it already had on the ground in Liberia: UNMIL, the United Nations Mission in Liberia. This article examines the question of whether UNMIL could have done more to contribute to the emergency response and attempts to draw some lessons from this experience for potential peacekeeper involvement in future public health emergencies. We find that UNMIL could have done more than it did within the terms of its mandate, although even if it had chosen to do so it may well have been hampered by a number of factors including its own capacities, the views of Troop Contributing Countries, and the approach taken by the Liberian government. We suggest this case can inform broader discussions over the provision of medical and other forms of humanitarian assistance by peacekeeping missions including those around the danger of politicizing humanitarian aid and peacekeepers doing more harm than good. Finally, we raise a concern that a reliance on peacekeepers to deliver health services during 'normal' times could foster a dangerous culture of dependency, hampering emergency responses if the need arises.
\end{abstract}

Keywords: Ebola, United Nations, Security Council, Peacekeeping; Liberia; UNMIL

\section{Introduction}

On 23 March 2014, the World Health Organization (WHO) reported on its Disease Outbreak News website that the Guinean government had informed it of a virulent form of Ebola Virus Disease (EVD) affecting the South-Eastern region of the country, with a case fatality rate of $59 \%$ (29 deaths out of 49 cases). ${ }^{1}$ The same day, Médecins sans Frontières released a statement reporting that it had launched an emergency response in collaboration with the Guinean Ministry of Health. ${ }^{2}$ Seven days later, on 30 March, the Liberian Ministry of Health reported its first two confirmed cases of EVD to WHO, followed by Sierra Leone in late May. From that point on, there were near daily reports of new EVD cases in Guinea, Liberia and Sierra Leone. In early August, the spread of the disease into Nigeria, and the repatriation of two infected health workers to the United States, provided the catalyst for the Director-General of the WHO to convene an Emergency Committee under the International Health 
Regulations and formally declare the outbreak a Public Health Emergency of International Concern (PHEIC). ${ }^{3}$

Although assistance to the region gradually began to increase following the declaration of a PHEIC, the meeting of the UN Security Council on 18 September represented a major turning-point in the international response. At that meeting, the Security Council passed Resolution 2177 (2014), determining that the 'unprecedented extent of the Ebola outbreak in Africa constitutes a threat to international peace and security'. The operative clauses of that Resolution called on a range of actors to do more, including the governments of Sierra Leone, Liberia and Guinea; the African Union; ECOWAS; the EU; WHO; UNHAS (the United Nations Humanitarian Air Service); and other UN Member States. It also called on governments in the region to lift border restrictions that had been imposed as a result of the outbreak. At the same time, the Council welcomed "the intention of the Secretary-General to convene a high-level meeting on the margins of the sixty-ninth United Nations General Assembly to urge an exceptional and vigorous response to the Ebola outbreak", 5 signalling its approval of the creation of UNMEER, the United Nations Mission for Ebola Emergency Response. ${ }^{6}$.

Whilst the Security Council even discussing a health issue was unusual (although not unique - it has periodically discussed HIV/AIDS since 2000), the 201415 Ebola outbreak was the first example of the Security Council taking on a major leadership role in response to a public health emergency. Certainly, however, the Council had a longstanding interest in West Africa. Indeed, long before the creation of UNMEER, the Council had a mission present in one of the most severely affected countries - UNMIL (the United Nations Mission in Liberia). At the time Ebola struck, UNMIL was in its 'drawdown' phase, designed to deliver "a successful transition of complete security responsibility" to the Liberian government in $2016^{7}$. UNMIL was not a mission designed to deal with a major public health emergency and it was only present in one of the three most affected countries. However, the drawdown continued through the crucial early months of the outbreak (and in August the Secretary-General recommended that it continue as planned ${ }^{8}$ ) despite the fact that "the mission in Liberia sent increasingly dire cables [to WHO] about the virus, calling for help from [WHO Executive-Director] Dr. Chan and others about what to do." 9

Given the widespread criticism over the tardiness of the international response (a PHEIC was not declared until 8 August and UNMEER was only established in 
September - almost six months after the first cases were detected, by which time there had been over 5,000 confirmed, probable or suspected cases and 2622 deaths ${ }^{10}$ ), there is a case to be made that the UN, and particularly the Security Council, failed to make best use of the potential resource it had in UNMIL during the early stage of the outbreak. Michael R Snyder, for example, wrote (prior to the Security Council's first Ebola meeting) that

[UNMIL's] mandate includes the provision of humanitarian assistance and, crucially, the protection of civilians. In the past, this mostly meant protection against armed groups; however, UNMIL now needs to interpret this language to mean supporting the government in its effort to protect the population against a deadly pathogen.

The delay in mounting a coordinated response on the part of the UN, particularly between the WHO and Department of Peacekeeping Operations, could be seen as all the more puzzling given there appeared to be a precedent: MONUC (the UN's Mission in the Democratic Republic of Congo) had played a role in providing logistical support and communications capabilities during an EVD outbreak in Democratic Republic of Congo seven years earlier. ${ }^{12}$

In this article, we examine the question of whether UNMIL could and should have done more with the forces it already had deployed in Liberia to contribute to the emergency response. In particular, given the concerns that the UN mission had about the capacity of the Liberian government to respond to the crisis, we consider the effect of the mission drawdown as security and health personnel crises unfolded around the country at the height of the outbreak. The broader question underlying the analysis of this case is whether, given the recent emphasis on civilian protection in peacekeeping mandates and the Security Council's apparent expanding role in global disease response, public health emergencies could and should become a "new peacekeeping mission'.

We begin by briefly outlining the context of the outbreak in Liberia before looking at whether UNMIL had the necessary authorization and capacity to play a greater role than it did. In the final section of the paper we shift the focus to look at issues of appropriateness, drawing out some lessons from the Liberian Ebola case to shed light on the issue of whether or not peacekeepers should be used to address 
future public health emergencies in the developing countries in which they are often deployed.

We find that UNMIL could have done more than it did within the terms of its mandate, although even if it had chosen to do so it may well have been hampered by a number of factors including its own capacities, the view of the Troop Contributing Countries (TCCs) involved, and the approach taken by the Liberian government. Despite these limitations, continuing the drawdown process and largely confining UNMIL troops to their barracks through the first months of the outbreak reduced the overall response capacity available in Liberia - and included the effective withdrawal of vital health services that the mission had previously provided. More generally, we suggest that this case can inform broader discussions over the provision of medical and other forms of humanitarian assistance by peacekeeping missions, including those around the dangers of politicizing humanitarian aid and of peacekeepers doing more harm than good. ${ }^{13}$ Overall, we argue that peacekeeping missions may have a minor supporting role to play, but they are not a reliable mechanism for responding to public health emergencies. It is important that the lessons learned from Liberia's EVD outbreak so not lead them to be seen in those terms, even if the Security Council continues to carve out a role for itself as a leader in the field of 'global health security'.

Finally, we suggest that UNMIL's pre-Ebola practices may contain some valuable lessons about the desirability of peacekeeping missions providing medical services to civilian populations even outside of public health emergencies. Whilst such activities can be understood in both humanitarian and strategic terms (as a response to manifest need; and as a way of building positive relations with host communities), there is a danger of fostering dependence, unwittingly undermining the development of the sustainable domestic health systems that will be crucial to the response to any future public health crisis.

\section{UNMIL and the Ebola outbreak in Liberia}

The first EVD cases in Liberia were confirmed in Lofa county on 30 March 2014. On 2 April, an infected individual from Lofa travelled to the capital Monrovia, unknowingly bringing the disease to a major urban centre. ${ }^{14}$ From that point onwards infections increased exponentially. When the WHO declared Ebola a PHEIC on August $8^{\text {th }}$, there had been 294 deaths in the country as a result of the disease. ${ }^{15}$ By the 
time the Security Council met on 18 September this had increased to 1,459. Liberia was officially declared Ebola-free on 9 May 2015, by which stage the death toll stood at $4,716 .{ }^{16}$ A small number of further cases were diagnosed in June and July, before the country was once again declared officially Ebola Free on 3 September $2015 .{ }^{17}$

Originally created as a multidimensional peacekeeping operation to monitor the August 2003 ceasefire agreement that brought an end to Liberia's civil war, at the time the Ebola outbreak began UNMIL was in the second phase of its drawdown plan. ${ }^{18}$ From a peak of 15,520 troops in 2006, by June 2014 and the start of Liberia's EVD outbreak, the number had been reduced to just over $4,500 .{ }^{19}$ The potential impact of Ebola on these mission personnel quickly attracted attention, especially from TCCs. Several expressed concern for the safety of their personnel, and the Philippines announced on 23 August that it was withdrawing its 115 troops from the mission - despite assurances from Secretary-General Ban Ki-moon that the threat posed to them was limited:

All United Nations personnel in Liberia have been educated about the appropriate preventive measures that would minimize the risk of contracting Ebola, which is not airborne and requires direct contact with the bodily fluids of a symptomatic infected person or the deceased. I am therefore confident that United Nations personnel may continue their important work in Liberia. ${ }^{20}$

Nevertheless, the emergence of Ebola in areas where UNMIL units were stationed led to the mission's general advice to its units to close UNMIL facilities from public access. ${ }^{21}$ All personnel were restricted to essential movement only, and an isolation centre was created to screen personnel for possible infection. ${ }^{22}$ Despite these measures, the mission did suffer from infections. The first death of an UNMIL staff member from EVD came on 25 September; the second on 13 October.

At the end of August, the Secretary General reversed his recommendation from two weeks earlier and recommended a rollover of UNMIL's mandate for three months "to monitor the human rights situation and better facilitate humanitarian assistance during the crisis by helping maintain the necessary security conditions." 23 In a series of meetings in September 2014, the Security Council discussed the situation in Liberia, focusing largely on the efforts of the DPKO to keep UNMIL peacekeepers safe from the outbreak - although Karin Landgren, Head of UNMIL, also briefed the Council on the situation in Liberia more generally and reported that 
UNMIL "had turned its full focus on Ebola since late July and was working in four areas: security and rule of law, logistics, communications and outreach and coordination at the central and country level." Even once they got underway, however, these types of activity were in the vast majority of cases 'supportive' and indirect: donating vehicles for use against Ebola, providing medical training to local health workers, and providing public communication on Ebola prevention via UNMIL radio and community outreach. ${ }^{24}$ The Mission did not play an active role in treating Ebola patients (other than its own personnel) and (despite its security provision role) explicitly distanced itself from involvement in the Liberian government's diseasecontainment-related security operations such as the isolation of the West Point district of Monrovia, which led to violent clashes between the public and the Liberian security forces. ${ }^{25}$

These decisions to play only a supporting role were in many ways understandable, not least due to the need to keep concerned TCCs in the mission and a desire to avoid associating the mission with the (inappropriate in the view of many) militarised response of the Liberian government. ${ }^{26}$ Nevertheless, these decisions had considerable impact given the mission's previous practice in delivering both health and security services, which we discuss in the following section. Effectively returning mission personnel to their barracks once EVD emerged did not, therefore, represent merely a failure to step up and provide direct assistance, but in fact led to the effective withdrawal of assistance (both security and medical) that had previously been provided. ${ }^{27}$ This was despite the fact that the weaknesses of the Liberian health system were well-known (one of the reasons UNMIL was so active in its medical outreach activities), and that in 2014 the mission's progress report expressed concerns about the political and security practices of the Liberian government. The relationship between these weaknesses and the Ebola response was not examined in depth in the August report. ${ }^{28}$ Indeed it was not until the Security Council session in early September that the head of UNMIL, Karin Landgren, openly doubted the effectiveness of the Liberian government's response. ${ }^{29}$

These choices may be interpreted - and indeed were by some - as a missed opportunity to make a fuller contribution in the crucial early months of the outbreak. But they also raise some more general questions about the role of peacekeeping missions in public health emergencies. The idea that UNMIL could and should have done more rests on a series of underlying assumptions: that peacekeeping missions (in 
particular in this case UNMIL) are authorised to play a greater role; that they are capable of doing so safely and effectively; and that they are an appropriate mechanism for carrying out such tasks. In the following sections of this paper we discuss the issues of authorization and capacity, before turning to a discussion of the appropriateness of peacekeeping forces as a mechanism for addressing public health emergencies in the developing countries in which they are most-often deployed.

\section{Authorization}

The first assumption that we examine is that UNMIL was authorized to play a more active role in responding to Ebola than it did. This is not uncontroversial - and such a role could entail various things, from providing security to allow humanitarian aid agencies to work to more direct forms of medical assistance such as treatment by UNMIL's medical staff.

The mandate is always the starting point for examining issues of peacekeeping authorization, with the mandate for each mission being specified in the relevant resolution(s) of the UN Security Council. The original UNMIL mandate, as set out by the Security Council, acting under Chapter VII of the UN Charter, in Resolution 1509 (2003) outlined a 19-point mandate, the most important clauses of which charged UNMIL with the tasks of observing and monitoring the ceasefire; assisting with the development and operation of cantonment sites; developing and implementing a DDRR action plan; and providing security services at key institutions. ${ }^{30}$

Resolution 2116 (2013), the authorizing resolution in force at the beginning of the Ebola outbreak, reaffirmed that "UNMIL's primary tasks are to continue to support the Government in order to solidify peace and stability in Liberia and to protect civilians". ${ }^{31}$ Civilian protection was thus a part of the mandate, although this did not include an explicit requirement to deliver medical aid or other forms of humanitarian assistance. Indeed the mandate was clear that UNMIL's mission was to play a facilitating rather than a direct humanitarian assistance role:

(k) to facilitate the provision of humanitarian assistance, including by helping to establish the necessary security conditions.

As discussed in the previous section, in September 2014, the Security Council passed Resolution 2176 which expressed "grave concern about the extent of the 
outbreak of the Ebola virus" and extended UNMIL's mandate to December 2014 (in the process deferring the planned drawdown). In that Resolution the Council noted that it was

\begin{abstract}
Expressing deep appreciation for and commending the continued contribution and commitment of United Nations personnel, especially the troop- and police contributing countries of the United Nations Mission in Liberia (UNMIL), to assist in consolidating peace and stability in Liberia, and the efforts of the Special Representative of the Secretary-General ${ }^{32}$
\end{abstract}

That was followed on 15 December 2014 by Resolution 2190 (2014) which repeated the sentiments of the September resolution and updated UNMIL's mandate. The humanitarian assistance mandate given to the mission remained very similar to that of 2003:

(b)(i) to facilitate the provision of humanitarian assistance, including in collaboration with the Government of Liberia, and those supporting it, and by helping to establish the necessary security conditions. ${ }^{33}$

What can be said, therefore, is that, notwithstanding the overall civilian protection mandate, there is nothing in UNMIL's mandate - even as renewed during the Ebola outbreak - that tasked it with directly providing humanitarian assistance, although it was given a role in facilitating the provision of such assistance by other parties through helping to establish the necessary security conditions.

In addition to each mission's mandate, the DPKO has also produced a range of other guidance and information relevant to peacekeeper provision of humanitarian (including medical) assistance, perhaps the most notable of which is the 2008 Principles and Guidelines to Peacekeeping Operations (commonly known as the 'Capstone Doctrine') that provides generic guidance on the roles and responsibilities of peacekeepers serving in UN missions. ${ }^{34}$ Principles and Guidelines includes material concerning the organization, management and support to missions and states clearly that the "core business" of peacekeepers is to stabilize the situation and provide a secure environment for civilians and humanitarian actors. ${ }^{35}$ When it comes to playing a more direct role in the delivery of humanitarian assistance, meanwhile, the document notes that responsibility: 
rests primarily with the relevant civilian United Nations specialized agencies, funds and programmes, as well as the range of independent, international and local NGOs which are usually active alongside a United Nations peacekeeping operation. The primary role of United Nations peacekeeping operations with regard to the provision of humanitarian assistance is to provide a secure and stable environment within which humanitarian actors may carry out their activities. $^{36}$

Could it nevertheless have been argued that UNMIL was authorised to play a more direct role in delivering medical aid during the EVD outbreak even without a specific request from the Security Council? In our view it possibly could. There are two particular areas where we find official endorsement of a role for peacekeepers in the direct delivery of humanitarian medical aid (rather than solely as facilitators of humanitarian access): Civil Military Cooperation (CIMIC), which includes health care delivery and services (sometimes referred to as Quick Impact Projects' [QIPs]) ${ }^{37}$ and cases of extreme emergency.

First, the DPKO does recommend that in some circumstances missions should engage in QIPs, designed to benefit the population through small-scale infrastructure and/or public communication projects, which may include a health/medical component - although it stresses that these are "not a substitute for humanitarian and/or development assistance". ${ }^{38}$ As we discuss below, UNMIL has a long trackrecord of engaging in such projects in the health field, with medical outreach and related activities being undertaken by a number of different national contingents over the history of the mission. The impetus for such activities frequently comes from the contingents on the ground rather than New York. The UN's Department of Field Support (DFS), responsible for the day-to-day management of peacekeeping operations, states that all civil assistance, including health care delivery, should be coordinated with other humanitarian entities and subject to review by the UN-CIMIC and the mission approval process'. ${ }^{39}$

The other set of circumstances in which peacekeepers are authorized to play an explicit humanitarian role is in cases of extreme emergency. OCHA provides guidance on the relationship between civilian and military actors during complex emergencies $^{40}$ as well as mission specific guidance; the priority in both cases being to ensure that conflict is avoided between military and humanitarian actors and that the principles of neutrality and impartiality of humanitarian aid provision are respected (and are seen to be respected). In terms of coordination, these guidelines seek to 
forward the broader UN integration policy to "Deliver as One," whilst at the same time ensuring that peacekeepers maintain primary responsibility for a mission's political and security objectives, whilst humanitarian agencies lead the response in that sector. The intention is to see these roles blend only in situations where an

emergency is so great as to require it, for example where "only the use of military assets can meet a critical humanitarian need", and even then only as a "last resort". 41 The DPKO has similarly made reference to "emergency response periods" in which there is a potential need for humanitarian assistance to be provided directly by a peacekeeping mission rather than by specialised humanitarian agencies. In such cases the only objective is to save lives, ensure protection, and meet basic, urgent needs. The DPKO goes on to note that in these situations, "it is important to keep longerterm objectives in mind and begin planning for the more comprehensive humanitarian programmes that will be possible in a more stable environment." ${ }^{, 42}$

It would surely be the case that the Ebola outbreak in Liberia as it developed through 2014 would qualify as such an 'emergency', justifying UNMIL playing a greater role without compromising the terms of its mandate, and without the mission contravening more general UN guidelines and principles. Particularly in the early stages of the outbreak, the acute shortage of trained medical personnel reduced any danger of problematic overlap with the activities of humanitarian aid agencies. That UNMIL did not use the developing emergency as a basis to justify doing more suggests that issues of capacity and competence were the primary limitation. Certainly that is the implication to be derived from the comments of Under-Secretary-General for UN Peacekeeping Operations Hervé Ladsous when he stated that 'a peacekeeping mission is not a public health operation [as] "this is not what we are trained for". ${ }^{43}$

\section{Capacity and competence}

As is the case with all peacekeeping operations, UNMIL was deployed with its own medical services whose primary role was (and is) to provide healthcare services to mission staff (both military and civilian) during their deployment. ${ }^{44}$ Yet it is clear from UNMIL's public communications that, prior to Ebola, assisting with logistics and even in the direct delivery of medical services to local populations in the mission area, and not just to mission personnel, was a significant part of their daily work - and also an important aspect of the 'public face' of the mission. 
Indeed, the extent to which the outer provinces of Liberia in particular were dependent upon the presence and assistance of UNMIL is striking. UNMIL has provided the only supply chain for moving essential logistical equipment, as well as personnel from the Liberian National Police force and medical staff to the outer provinces. In the (six-month) rainy season 'roads become impassable and cannot sustain major logistics movements...There are no in-country commercial alternatives to the UNMIL military engineering units that keep critical supply lines open; there are also serious shortfalls in the national medical system'. UNMIL - despite the drawdown - was still required to 'support civilian personnel, including police [and presumably medical staff], deployed throughout the country' ${ }^{45}$ This situation has resulted in two dependencies - a reliance on UNMIL to facilitate access to Liberian medical staff in the outer provinces, or failing that, on UNMIL itself to provide medical assistance to Liberian citizens.

The mission's publication UNMIL Today frequently included reports of troops' involvement in providing medical services to civilian populations - in particular (but not only) women and children. Examples include reports of medical outreach initiatives in Bensonville, near Monrovia, where more that 300 patients were treated by Nigerian UNMIL medical personnel (reported June 2009); ${ }^{46}$ a paediatric de-worming programme along the Zorzor - Voinjama road (carried out by Bangladeshi troops and reported November 2009) ${ }^{47}$; a weekly 'meet the doctor' organised by the Bangladeshi battalion at Camp Charlie in Ganta which, at the time of the report in July 2010, was claimed to have treated over 1350 patients ${ }^{48}$; a Pakistani Battalion-run clinic providing medical assistance to the blind and visually impaired in Tubmanburg, Bomi County (reported July 2010) ${ }^{49}$; and an outreach programme, again run by troops from Pakistan, in Careysburg, Montserrado County, where over 500 received treatment (reported August 2010). ${ }^{50}$ The UNMIL Facebook page - which began in 2011 - has similarly featured regular reports of medical outreach activities. These have included treating 900 residents of Plumkor Community in Brewerville, Montserrado County ${ }^{51}$; offering training to medical staff in a Liberian hospital ${ }^{52}$; a Christmas-time medical outreach day at Virginia Christian Academy near River View, Monrovia ${ }^{53}$; and countless other examples of outreach days in communities including students at the Darussalam International Islamic Mission, ${ }^{54}$ inmates at Monrovia Central Prison, ${ }^{55}$ and the Hotel Africa community ${ }^{56}$. 
Of course, neither UNMIL's important role in providing logistical capabilities to the Liberian health sector nor the medical outreach initiatives (most of which were for limited periods of time and involved relatively small numbers of UNMIL personnel) meant that the mission was in a position (either in terms of manpower or equipment) to play a major part in responding to a public health emergency on the scale of Ebola. But they do indicate that it may have been able to play a greater part than it did, and it remains striking that the first reaction was for battalions to return to barracks - and also, as we noted above, that the vast majority of existing medical outreach activities ceased once the Ebola outbreak began.

One obvious lesson here is that the views and demands of TCCs were a key capacity constraint on the mission. The withdrawal of the Philippines contingent and the reluctance of other TCCs to see their troops put 'in harm's way' in a rapidly developing health crisis certainly limited the extent to which peacekeepers could play a more active role. But even without those constraints, there were good reasons to question whether the UNMIL medical services could have effectively (and safely) made a significant contribution to controlling Ebola in public health terms (as opposed to the mission making a greater potential logistical and security contribution if it had not continued drawdown - a point to which we return below).

For one, there had over a number of years been serious criticisms of the quality and safety of UNMIL's medical services. In 2009, the UN's Office of Internal Oversight Services' (OIOS) audit of UNMIL identified failures in the quality of medical care being provided in this mission to both troops and civilian populations. ${ }^{57}$ Amongst other things, it found a lack of standard operating procedures to guide TCC's provision of medical care; no professional support and training available to upgrade medical personnel skills; inadequate hygiene in TCC clinics; and failures to comply with WHO guidelines on the disposal of medical waste. During the audit, the OIOS also found that peacekeepers were providing medical treatment to local populations despite their clinics not meeting basic medical standards for hygiene and waste management. All of this means that there must be caution in the presumption that UNMIL's medical services were well-placed to assist with an infectious disease outbreak as deadly and virulent as EVD. Indeed, as noted by the OIOS audit, one of the major health concerns surrounding UN peacekeeping is the potential for peacekeepers to be "vectors" of disease - to spread infection through the local community. ${ }^{58}$ As well as the obvious negative health impact on affected civilians, 
such events can have other damaging effects, including straining relations between a mission and the host community.

Where UNMIL may have been better-placed to play a more active role earlier than it did is in relation to logistical support (continuing or augmenting its previous role), and in assisting the Liberian government with spread of information about the virus throughout the provinces. However, the drawdown had a significant detrimental effect on UNMIL's provincial presence. As we noted above, UNMIL was one of few international actors that had a strong logistical capability in the provinces prior to the outbreak, and it was noted during the Ebola crisis that the peacekeeping mission in Liberia had the comparative advantage to other UN agencies in terms of its geographic reach and political leverage. ${ }^{59}$ But by the time of the Security Council session on 9 September 2014 it was reported that UNMIL had completed drawdown from four provinces and was now only present in only seven of 15 . Improving the limited capacity to provide rapid response in the outer provinces was later noted by WHO as vital to containing the outbreak. ${ }^{60}$

The lack of international coordination in responding to the Ebola outbreak also hampered UNMIL's response to the emergency in Liberia. For example, in late July the UN had asked US CDC not publicly release projected end-of-year Ebola cases, in part because UNMIL had reported that the situation was tense on the ground. This advice was not followed and UNMIL - still in drawdown mode at the time - had to quickly prepare for a security response to riots and shootings in Monrovia. ${ }^{61}$ The delay in WHO Headquarters convening an emergency committee to declare Ebola a PHEIC also impaired the ability of UNMIL to raise the alarm. Technically UNMIL could not request support to mount an emergency response action to the outbreak without prio action from WHO, the body authorised to declare a health emergency. If WHO Headquarters had acted sooner, there is the possibility that UNMIL Head of Mission may have had a greater opportunity to do more earlier..

In relation to assisting with security (a task which would on the fact of it seem to explicitly fit within the 'facilitating humanitarian access' provisions of the mission's mandate), one of the difficulties faced by the mission was the controversial nature of some of the Liberian government's own responses. Those responses became increasingly militarized over time - with one of the most high-profile incidents being the attempt to forcibly quarantine the West Point district of Monrovia, an attempt that culminated in clashes between the public and the security services. ${ }^{62}$ Not only was 
UNMIL not involved in such operations, it was at pains to distance itself from them. ${ }^{63}$ This dimension of the Ebola response points to the difficult choices that peacekeeping missions such as UNMIL face when dealing with complex emergencies within their mission areas. In the next part of this paper we go on to unpack some of these issues, considering the question of whether or not, where present on the ground, peacekeeping missions are appropriate bodies for responding to rapidly-developing public health emergencies.

\section{Peacekeepers: A role in responding to health emergencies?}

In the previous section we argued that UNMIL could have done more within the terms of its mandate, although the types of contribution it was in a position to make were limited by a range of factors including the views of the TCCs involved, the resources and competencies of the mission, problems of inter-agency coordination, and the actions of the host government. But aside from these issues, what can we say about the appropriate role of peacekeepers in responding to the Ebola outbreak and to future public health emergencies?

It is clearly not the case - and nobody would try to argue - that peacekeepers are ideally suited to responding to major disease outbreaks. The question, rather, is whether, in the absence of other agencies better-placed to take on the burden of the task, it is appropriate for peacekeepers who are already on the ground to play a role as emergency 'first responders'.

It was noted in the Introduction to a recent special issue of Third World Quarterly on the 'local turn' in peacebuilding that critics often point to the 'shallowness of interventions that serve the intervener better than the targets of intervention. Overall, however, practices remain as they were, and peacebuilding in post-conflict contexts remains volatile'. ${ }^{64}$ Liberia, even before the Ebola outbreak, was a country struggling to live up to the liberal peace ideal. The dependence we described above on external agencies, including UNMIL, for local healthcare service delivery - a problem identified nted long before EVD - points to a collective failure by the national government and international donors to build domestic health system capacities. ${ }^{65}$ As was widely noted, the Ebola outbreak graphically illustrated the weaknesses of the health infrastructure in Liberia (as well as the other two mostaffected countries). Liberia had resided near the bottom of all of the league tables for health indicators and health system development for many years before the outbreak. 
In terms of life expectancy it ranked $166^{\text {th }}$ in the world. ${ }^{66}$ On the league table of physicians per 1,000 people it did even worse, being ranked 194th in the world (jointly with Sierra Leone, at 0.03 physicians per 1,000 people). ${ }^{67}$ The Ebola outbreak (and certainly its scale) was to a great extent the product of a decade and more of failure to transition Liberia to an effective state.

Yet, taking the Liberian health system as it was in 2014, what can the UNMIL experience reveal about the suitability of peacekeeping missions as first responders to major public health crises? If the Security Council continues to play a leading role in international responses to such events, it may be tempted to view the peacekeeping forces which it has stationed around the world as a potential tool - as might the Secretary-General, given his recommendation of extending the UNMIL mandate to enable it to assist in the response. In this section we raise two doubts about the appropriateness of peacekeeping forces playing a significant role in responding (especially in a medical capacity) to health emergencies. Whilst, as we have discussed above, there were opportunities for UNMIL to have done more, there are dangers (and the potential for dangerous precedents) that must be acknowledged before advocating that peacekeepers should be in the front line of responding to health emergencies. In this section we discuss: first, the danger of humanitarian aid becoming politicised and second, the potential that even well-intentioned actions could do more harm than good.

\section{Politicization}

One of the potential downsides of the engagement of military forces (even those serving in blue helmets) in delivering aid is that it can undermine the perceived neutrality of humanitarian assistance. This fact is well-recognised by the UN itself. In discussing QIPs, Principles and Guidelines recommends that missions should consult with humanitarian actors and:

be aware that humanitarian actors may have concerns about the characterization of QIPs, or Civil Military Coordination (CIMIC) projects, "hearts and minds" activities, or other security or recovery projects as being of a humanitarian nature, when they see these as primarily serving political, security or reconstruction priorities. ${ }^{68}$ 
A clear expression of this fear from the humanitarian aid community's side was seen in 1997 when Cornelio Sommaruga, then President of the International Committee of the Red Cross (ICRC), argued that the separation of peacekeeping duties from the provision of humanitarian assistance was essential:

UN military missions are an essential component of successful conflict management; in certain anarchic situations they may prove indispensable in securing respect for international humanitarian law and thus restoring the necessary security environment for the conduct of humanitarian activities. That being said, peacekeeping, and especially peace-enforcement operations, should be clearly distinct in character from humanitarian activities. Military forces should not be directly involved in humanitarian action, as this would associate humanitarian organizations, in the minds of the authorities and the population, with political or military objectives which go beyond humanitarian concerns. ${ }^{69}$

Similar concerns were apparent in the 2011 WHO Global Health Cluster's position paper on civil-military roles and responsibilities. That report noted that neither the IASC nor the Security Council has adequately addressed the division of responsibilities that reflect the multidisciplinary UN mission environment. The concern, as voiced by the WHO was that:

[T]his blending of strategies and tactics serves to undermine the international humanitarian community's core humanitarian principles. The integrated mission concept developed by the UN follows a similar trend. Although there are significant attempts to protect the humanitarian space within integrated missions, the concept foresees the integration of different agencies and components into an overall political/strategic crisis management framework. This can blur the lines between the UN's different political and humanitarian branches, with predictably negative results. ${ }^{70}$

Whilst protection of humanitarian space was not a major problem in the case of Liberia (although the mission was reluctant to associate itself with the government's controversial security operations for fear of politicization), the transfer of responsibility was proving a problem, particularly to local government structures outside of Monrovia. $^{71}$ In this respect, of course, Liberia was not typical of all peacekeeping missions: this was a relatively stable country in the midst of a drawdown of the UN presence, without the kinds of antagonism that other peacekeeping missions can face. In the Liberia case, indeed, the widespread acceptance of UNMIL's presence was itself part of the problem, creating a worrying 
dependence on the mission for access outside of Monrovia at a time when it was continuing with drawdown despite the developing humanitarian emergency. Yet in other cases peacekeeping missions are more controversial, and their engagement in delivering humanitarian assistance could pose risks to perceptions of aid neutrality.

\section{Doing more harm than good}

A second danger relates to Lasdous' comment that "this is not what we are trained for", and relates to the possibility that peacekeeping missions attempting to provide assistance in cases of a major public health emergency could unwittingly end up doing more harm than good. We have already mentioned the findings of the OIOS audit of UNMIL's medical services that there were worrying failures - including in hygiene standards in facilities used to provide treatment to the civilian population. Whilst steps had been taken to address these issues in the intervening years, the high standards of infection control required in the treatment of infectious diseases such as Ebola point to the potential dangers of under-equipped and ill-prepared interventions - however well-intentioned. The experience of the UNMIH mission in Haiti, which was accused of having been responsible for a serious cholera outbreak following the 2010 earthquake, ${ }^{72}$ serves as a warning about the importance of infection control, and the possible implications of peacekeeping missions failing to maintain strict standards in this respect.

In terms of the potential for logistical and security assistance to do more harm than good the risks are perhaps more limited - but are not entirely absent. Even if there is a mandate provision to respond to a health emergency, the Security Council remains dependent on TCCs to provide it with the personnel and other resources that it needs. This posed a problem in the Ebola outbreak, with TCCs being extremely wary of exposing their troops to risk of infection and would likely similarly arise in future situations. Difficult relationships and policy disagreements with host governments can also pose problems - clearly a factor in UNMIL's desire to disassociate itself from some of the security operations of the Liberian government. Even though (indeed precisely because) they are humanitarian emergencies, major outbreak events can be deeply politicized, with governments often opting to take unpopular and authoritarian actions in the name of disease control. There are clearly risks in the UN becoming associated with such actions, not least given the Organization's position of support for human rights around the world. Engagement in 
such controversial activities could create new complications both for the mission itself and for the UN family as a whole.

\section{Conclusions}

This discussion leads us to two final observations on the role of UNMIL in the Liberian Ebola outbreak, and more generally on the potential role of peacekeeping missions in responding to public health emergencies in the developing world.

First, there may have been opportunities for UNMIL to play a greater role than it did - especially early in the outbreak - but it could never have been an optimal response mechanism for a number of reasons. Whilst the mission probably did have scope under its mandate to justify a bigger role (especially, for example, in logistics and support in the provinces), it suffered a number of limitations including the willingness of TCCs to allow their personnel to play this role and the effects that drawdown had already begun to have. The actions of the Liberian government also arguably made it more politically difficult for UNMIL to play a more significant role in providing the security conditions under which the humanitarian response could operate effectively. What is more, there are important questions to be asked about the competence and capacity of some TCCs medical services when confronting a deadly infectious disease threat. At the very least, however, we would argue that the drawdown should have been halted at an earlier stage in the outbreak, a decision that may have allowed UNMIL to contribute more to the developing international effort.

Second, there are broader questions raised by the Liberia case about the provision of medical assistance to civilians by peacekeeping missions. Whilst we would accept that there is a case for mission medics to play a role in emergency situations such as the Ebola outbreak, the desirability of such a role in 'normal' times is more debateable. Indeed in this case the reliance on external actors, including UNMIL, to 'prop up' a failing national health system by delivering services seems to have been one of the underlying causes of the country's failure to develop a sustainable national health system. Greater attention needs to be paid to peacekeeper involvement in such activities, and how transitions can be made to national 'ownership', shifting health care delivery from blue helmets to local authorities. Ebola, coupled with the UNMIL drawdown, revealed the over-dependence of national service provision on external support - including that provided by what was always designed to be a temporary peacekeeping mission. This is a moral hazard for 
peacekeepers, and is one that all humanitarian actors feed into, but the consequences may not become tragically apparent until a country is thrown into the perfect storm of health insecurity, as happened with in Ebola outbreak. 


\section{Notes}

${ }^{1}$ WHO, "Ebola virus in Guinea."
${ }^{2}$ MSF, "Ebola Epidemic Declared."
${ }^{3}$ Enserik. "WHO declares Ebola emergency."
${ }^{4}$ UN Security Council, S/RES/ 2177, 1.
${ }^{5}$ UN Security Council, S/RES/ 2177, 3.
${ }^{6}$ UN General Assembly, A/RES/69/1. UNMEER was based in Ghana and initially led by Assistant Secretary General for Field Support Anthony Banbury. Banbury had already been appointed 'Ebola Crisis manager' by the SG, on September $8^{\text {th }}$. UN General Assembly/Security Council, A/69/389S/2014/679

${ }^{7}$ UN Security Council, S/RES/2066.

${ }^{8}$ UN Secretary General, S/2014.598

${ }^{9}$ Sengupta, "Effort on Ebola". Chan's office, according to Sengupta, claimed that it had no record of receiving the cables.

${ }^{10}$ WHO, "Situation Report. 18 September."

${ }^{11}$ Snyder, "What role for peacekeepers?"

${ }^{12}$ WHO, 'Ebola haemorrhagic fever in the Democratic Republic of Congo'.

${ }^{13}$ For further discussion of these issues see [anonymised]

${ }^{14}$ WHO, "Liberia: "overwhelmed with Ebola."

${ }^{15}$ WHO AFRO, "Ebola update 8 August".

${ }^{16}$ WHO, "Situation Report - 6 May."

17 WHO, "Ebola transmission in Liberia over".

${ }^{18}$ UN Security Council, S/RES/2066.

${ }^{19}$ UN Secretary General, S/2014.598, 14.

${ }^{20}$ Quoted in Lynch, "Ban Says Troops Safe."

${ }^{21}$ Menkor, "Ebola Fear Closes UNMIL."

${ }^{22}$ Snyder, "What role for peacekeepers?"

${ }^{23}$ UN, "Citing Ebola Outbreak's Toll."

${ }^{24}$ Wesee, "Liberia: UNMIL, UN Commit."

${ }^{25}$ UN, "Citing Ebola Outbreak's Toll."

${ }^{26}$ Chatham House, "Combating Ebola in Liberia", 4.

${ }^{27}$ All Africa, "Samukai Outlines Effects."

${ }^{28}$ UN Security Council, S/2014/598, 5, 11.

${ }^{29}$ UN Security Council, S/PV.7260, 4.

${ }^{30}$ UN Security Council, S/RES/1509.

${ }^{31}$ UN Security Council, S/RES/2116.

${ }^{32}$ UN Security Council, S/RES/2176.

${ }^{33}$ UN Security Council, S/RES/2190.

${ }^{34}$ UN DPKO, Principles and Guidelines

${ }^{35}$ UN DPKO, Principles and Guidelines, Figure 2, 23-24.

${ }^{36}$ UN DPKO, Principles and Guidelines, 30.

${ }^{37}$ UN DPKO, “Civil-military coordination.” Indeed, QIPs were rolled out to support country health teams when government funds were inexplicably held up in reaching the province. See UN Security Council, S/PV.7260, 5.

${ }^{38}$ UN DPKO, Principles and Guidelines, 30.

${ }^{39}$ UN DPKO, "Civil-military coordination."

${ }^{40}$ OCHA, "Humanitarian Civil-Military Coordination."

${ }^{41}$ OCHA, "Civil-Military Guidelines", xi.

${ }^{42}$ UN Peacekeeping Operations, Handbook on Multidimensional Peacekeeping, 175.

${ }^{43}$ UN News, "UN will 'stay the course'."

${ }^{44}$ UN Peacekeeping Operations, Medical Support Manual, para.1.01.

45 UN Secretary General, S/2014.598, 6, 15.

${ }^{46}$ UNMIL, "Medical Outreach in Gurmoshor."

${ }^{47}$ UNMIL, "Banengr-12 Deworming Exercise."

${ }^{48}$ UNMIL, "Meet the Doctor"

${ }^{49}$ UN MIL, "PakEng-13 Helps Blind."

${ }^{50}$ UNMIL, "PakEngr-14 in Medical Outreach."

${ }^{51}$ UNMIL, Facebook page, July 192012. 
${ }^{52}$ UNMIL, Facebook page, July 252012.

${ }^{53}$ UNMIL, Facebook page, December 172012.

${ }^{54}$ UNMIL, Facebook page, June 62013.

${ }^{55}$ UNMIL, Facebook page, October 92013.

${ }^{56}$ UNMIL, Facebook page, December 262013.

${ }^{57}$ UN OIOS, "Audit of UNMIL."

${ }^{58}$ For further discussion of this issue see [anonymised]

${ }^{59}$ UN Security Council S/2014/598, 10; UN Security Council, S/2014/644, 2.

${ }^{60}$ WHO, "Liberia: "overwhelmed with Ebola."”

${ }^{61}$ Karin Landgren quote in Chatham House, "Combating Ebola in Liberia", 2-3.

${ }^{62}$ Onishi. "Clashes Erupt."

${ }^{63}$ In a letter to the Security Council on 28 August 2014, Secretary-General Ban reported that: "Though it has not, and will not, enforce the Government-imposed isolation of affected areas, UNMIL will continue to facilitate the provision of humanitarian assistance, including by helping to provide the necessary security conditions, in accordance with Security Council resolution 1509 (2003)." UN Security Council, S/2014/644, 2.

${ }^{64}$ Hughes et al, "The struggle versus the song", 823.

${ }^{65}$ Downie, "The Road to Recovery"; Petita et al. "Implementing a Basic Package."

${ }^{66}$ WHO, "Life expectancy by country."

${ }^{67}$ Nationmaster, "Physicians per 1,000 people."

${ }^{68}$ UN DPKO. Principles and Guidelines, 30.

${ }^{69}$ Sommaruga, "Humanitarian action and peace-keeping."

${ }^{70} \mathrm{WHO}$, "Civil-military coordination", 11-12.

${ }^{71}$ UN Security Council, S/2014/598, 8; see also, Leonardsson and Rudd, “The 'local turn'.

${ }^{72}$ For a full discussion of this case see [removed for anonymity]

\section{Bibliography}

All Africa. "Liberia: Samukai Outlines Effects of Ebola - Wants Support to Lift Travel Ban and Statement to the UNSC by Defence Minister Brownie Samukai." All Africa, 11 September 2014. http://allafrica.com/stories/201409111254.html

Chatham House. Combating Ebola in Liberia: The Role of the International Community. Speaker: Karin Landgren. 10 November 2014.

http://www.chathamhouse.org/sites/files/chathamhouse/field/field_document/2014111 $\underline{\text { OEbolaLiberia.pdf }}$

Downie, Richard. The Road to Recovery: Rebuilding Liberia's Health System. Centre for International Strategic Studies. August 2012.

http://csis.org/files/publication/120822_Downie_RoadtoRecovery_web.pdf

Enserik, Martin. "WHO declares escalating Ebola outbreak an international emergency." Nature, 8 August 2014. http://news.sciencemag.org/africa/2014/08/whodeclares-escalating-ebola-outbreak-international-emergency

http://www.liberianobserver.com/security/ebola-fear-closes-unmil-facilities-nimba$\% \mathrm{E} 2 \% 80 \% 98$ indefinitely\%E2\%80\%99

Hughes, Caroline, Joakim Öjendal, Isabell Schierenbeck. 'The struggle versus the song - the local turn in peacebuilding: an introduction', Third World Quarterly, 36 (5) 2015. 
Leonardsson, H., and Rudd, G. "The 'local turn' in peacebuilding: a literature review of effective and emancipatory local peacebuilding", Third World Quarterly 36, no. 5: 825-839.

Lynch, C. "Ban Says U.N. Troops are Safe, Needed to Quash Ebola Unrest", Foreign Policy: The Cable, 2 September 2014.

http://thecable.foreignpolicy.com/posts/2014/09/02/ban_says_un_troops_are_safe_ne eded to quash_ebola_unrest

Menkor, I.F. "Ebola Fear Closes UNMIL Facilities In Nimba 'Indefinitely'.” Liberian Observer, 16 July 2014.

MSF. "Ebola Epidemic Declared in Guinea: MSF Launches Emergency Response." 23 March 2014. http://www.doctorswithoutborders.org/news-stories/field-news/ebolaepidemic-declared-guinea-msf-launches-emergency-response

Nationmaster, "Physicians per 1,000 people." 2015.

http://www.nationmaster.com/country-info/stats/Health/Physicians/Per-1,000-people

OCHA. 'Humanitarian Civil-Military Coordination: Publications'. 2014.

http://www.unocha.org/what-we-do/coordination-tools/UN-CMCoord/publications

OCHA. 'Civil-Military Guidelines and Reference for Complex Humanitarian Emergencies'. Geneva: United Nations, 2005.

https://docs.unocha.org/sites/dms/Documents/ENGLISH\%20VERSION\%20Guidelin es\%20for\%20Complex\%20Emergencies.pdf

Onishi, Norimitsu. "Clashes Erupt as Liberia Sets an Ebola Quarantine", New York Times, 21 August 2014.http://www.nytimes.com/2014/08/21/world/africa/ebolaoutbreak-liberia-quarantine.html? $\mathrm{r}=0$

Petit, Dörte, Egbert Sondorp, Susannah Mayhew, Maria Roura, Bayard Roberts. 'Implementing a Basic Package of Health Services in post-conflict Liberia: Perceptions of key stakeholders', Social Science and Medicine, 78, 2013.

Sengupta, Somini. "Effort on Ebola Hurt UN Chief", The New York Times, 6 January 2015.http://www.nytimes.com/2015/01/07/world/leader-of-world-healthorganization-defends-ebola-response.html? $\mathrm{r}=0$

Snyder, M.R. "What role for UN peacekeepers in tackling Ebola?" IPI Global Observatory, 8 September 2014.http://theglobalobservatory.org/2014/09/role-unpeacekeepers-unmil-tackling-ebola/

Sommaruga, Cornelio. 'Humanitarian action and peace-keeping operations', International Review of the Red Cross, No. 3171997. http://www.icrc.org/eng/resources/documents/misc/57jnj7.htm 
UN DPKO. Medical Support Manual for United Nations Peacekeeping Operations, $2^{\text {nd }}$ edn, 1999.

http://reliefweb.int/sites/reliefweb.int/files/resources/D196C0B0FF3A637BC1256DD 4004983B9-dpko-medical-1999.pdf

UN DPKO. "Civil-military coordination in UN Integrated Peacekeeping Missions". New York: United Nations, 2010.

https://docs.unocha.org/sites/dms/Documents/DPKO\%20UN-CIMIC\%20(2010).pdf

UN DPKO. United Nations Peacekeeping Operations: Principles and Guidelines. New York: United Nations, 2008.

UN General Assembly. A/RES/69/1, 19 September 2014. New York: United Nations.

UN General Assembly/Security Council. A/69/389-S/2014/679. "Identical letters dated 17 September 2014 from Secretary-General addressed to the President of General Assembly and the President of the Security Council. New York: United Nations.

UNMIL. 'Medical Outreach in Gurmoshor', UNMIL Today, 6 (1) 2009. Available at: http://reliefweb.int/sites/reliefweb.int/files/resources/EE2C0DBB1ACB36EF4925761 F001AD414-Full_Report.pdf.

UNMIL. 'Banengr-12 in Deworming Exercise', UNMIL Today 9 (6) 2009. Available at:

http://reliefweb.int/sites/reliefweb.int/files/resources/8CC159C1AD21E88949257687 $\underline{\underline{00185 A 05-F u l l \_R e p o r t . p d f}}$

UNIMIL. "“Meet the Doctor", UNMIL Today 7 (2) 2010. Available at: http://reliefweb.int/sites/reliefweb.int/files/resources/A73FCCFE15906B2C4925777B 0004A60F-Full_Report.pdf.

UNIMIL. 'PakEng-13 Helps the Blind', UNMIL Today 7 (2) 2010. Available at: http://reliefweb.int/sites/reliefweb.int/files/resources/A73FCCFE15906B2C4925777B 0004A60F-Full_Report.pdf.

UNMIL. 'PakEngr-14 in Medical Outreach', UNMIL Today 7 (3) 2010. Available at: http://reliefweb.int/sites/reliefweb.int/files/resources/C7B9AAE1AD84B9864925779 9000CE8DA-Full_Report.pdf.

UNMIL Facebook page, July 192012.

UNMIL Facebook page, July 252012

UNMIL Facebook page, December 172012

UNMIL Facebook page, June 62013

UNMIL Facebook page, October 92013 
UNMIL Facebook page, December 262013

UN News. “Citing Ebola Outbreak's Profound Toll on Liberia, Top Official Tells Security Council Plague Must Be Stopped in Its Tracks", 9 September 2014. http://www.un.org/press/en/2014/sc11553.doc.htm

UN News. "Ebola: UN will 'stay the course' in Liberia, peacekeeping chief says." UN News Centre, 11 September 2014. http://www.un.org/apps/news/story.asp?NewsID=48693\#.VXZSwc-qpBc

UN OIOS. 'Audit of the provision of medical services in UNMIL'. Assignment No.AP2008/626/08. 8 April 2009.

http://usun.state.gov/documents/organization/140720.pdf.

UN Security Council. S/2014/598. "Twenty-eighth progress report of the SecretaryGeneral on the United Nations Mission in Liberia." 15 August 2014. New York: United Nations.

UN Security Council. Letter dated 28 August 2014 from the Secretary-General addressed to the President of the Security Council. S/2014/644. 2 September 2014. http://www.un.org/ga/search/view_doc.asp?symbol=S/2014/644

UN Security Council. S/PV.7260. " $7260^{\text {th }}$ meeting of the Security Council, 9 September 2014.” New York: United Nations, 2014.

UN Security Council. S/RES/2066, 17 September 2012. New York: United Nations, 2012.

UN Security Council. S/RES/2176, 15 September 2014. New York: United Nations, 2014.

UN Security Council. S/RES/2177, 18 September 2014. New York: United Nations, 2014.

Wesee, B.P. "Liberia: UNMIL, UN Commit to Ebola Fight.” All Africa, 24 July 2014. http://allafrica.com/stories/201407241090.html

WHO. "Ebola haemorrhagic fever in the Democratic Republic of the Congo - update 2", Emergency Preparedness and Response, 20 September 2007. http://www.who.int/csr/don/2007_09_20/en/

WHO. 'Civil-military coordination during humanitarian health action'. Global Health Cluster. February 2011. http://www.who.int/hac/global_health_cluster/about/policy_strategy/ghc_position_pa per_civil_military_coord_2_feb2011.pdf?ua=1 
WHO. 'Ebola transmission in Liberia over. Nation enters 90-day intensive surveillance period', 3 September 2015.

http://www.who.int/mediacentre/news/statements/2015/ebola-transmission-overliberia/en/

WHO. "Ebola Response Roadmap Situation Report: 18 September 2014." http://apps.who.int/iris/bitstream/10665/133833/1/roadmapsitrep4_eng.pdf?ua=1

WHO. "Ebola Situation Report : 6 May 2015." http://apps.who.int/ebola/en/currentsituation/ebola-situation-report-6-may-2015

WHO. "Ebola virus disease in Guinea." 23 March 2014.

http://www.who.int/csr/don/2014_03_23_ebola/en/

WHO. "Liberia: a country - and its capital - are overwhelmed with Ebola cases." January 2015. http://www.who.int/csr/disease/ebola/one-year-report/liberia/en/

WHO. "Life expectancy by country.", Global Health Observatory Data Repository. 2015. http://apps.who.int/gho/data/node.main.688?lang=en

WHO AFRO. "Ebola virus disease, West Africa - update 8 August 2014." http://www.afro.who.int/en/clusters-a-programmes/dpc/epidemic-a-pandemic-alertand-response/outbreak-news/4241-ebola-virus-disease-west-africa-8-august2014.html 